Abstracta Iranica Abstracta Iranica

Revue bibliographique pour le domaine irano-aryen

Volume 32-33 | 2013

Comptes rendus des publications de 2009-2010

\title{
Sunil Kumar. The Ignored Elites: Turks, Mongols and a Persian Secretarial Class in the Early Delhi Sultanate
}

\section{Mauro Valdinoci}

\section{(2) OpenEdition}

12 Journals

\section{Electronic version}

URL: http://journals.openedition.org/abstractairanica/40633

DOI: 10.4000/abstractairanica.40633

ISSN: 1961-960X

Publisher:

CNRS (UMR 7528 Mondes iraniens et indiens), Éditions de l'IFRI

\section{Printed version}

Date of publication: 1 December 2013

ISSN: 0240-8910

\section{Electronic reference}

Mauro Valdinoci, «Sunil Kumar. The Ignored Elites: Turks, Mongols and a Persian Secretarial Class in the Early Delhi Sultanate », Abstracta Iranica [Online], Volume 32-33 | 2013, document 278, Online since 01 July 2016, connection on 02 October 2020. URL : http://journals.openedition.org/abstractairanica/ 40633 ; DOI : https://doi.org/10.4000/abstractairanica.40633

This text was automatically generated on 2 October 2020 .

Tous droits réservés 


\title{
Sunil Kumar. The Ignored Elites: Turks, Mongols and a Persian Secretarial Class in the Early Delhi Sultanate
}

\author{
Mauro Valdinoci
}

\section{REFERENCES}

Sunil Kumar. « The Ignored Elites: Turks, Mongols and a Persian Secretarial Class in the Early Delhi Sultanate ». Modern Asian Studies, vol. 43, n 1, 2009, p. 45-77.

1 The first part of this article discusses both the recruitment of frontiersmen by Delhi sultans to guard the Punjab from Mongol armies and the periodic seizure of power by frontier commanders. The second part explores the social and cultural backgrounds of these commanders. An analysis of Persian historical accounts from the period show that they ignored or misrepresented key characteristics of the Delhi sultans. According to the author, research on the objectives and prejudices of the Persian chroniclers is needed to "disengage their representations of a monolithic Islam, a hegemonic state and a timeless Persianate culture" (p. 49). By integrating the Delhi sultans' past in histories of the sultanate, the developments of the state and its ruling elites can be reassessed. The author argues that periodic migrations of military commanders with their retinues from the Afghanistan-Punjab frontier helped shape Muslim society and culture of the subcontinent. 


\section{AUTHORS}

\section{MAURO VALDINOCI}

University of Modena and Reggio Emilia 